\title{
PROFIL KEMAMPUAN BERPIKIR KRITIS DAN KEMAMPUAN METAKOGNITIF SISWA BERDASARKAN JENIS KELAMIN
}

\author{
Aditya Rahman $^{1}$, Indria Wahyuni ${ }^{2}$, Aat Noviani ${ }^{3}$ \\ 1,2,3 Jurusan Pendidikan Biologi, Fakultas Keguruan dan Ilmu Pendidikan, \\ Universitas Sultan Ageng Tirtayasa, Serang 42121, Indonesia \\ E-mail : adityaarahman9@gmail.com
}

\begin{abstract}
The aim of this study was to analyze the students critical thinking competence, and metacognitive competence based on genders through the learning model of problem based learning on the concept of environmentpollution at grade X of SMA 3 Kota Serang. The poppulation of the research was all students grade X MIPA, and the sample were 40 students at X MIPA 5 SMAN 3 Kota Serang City. This research used purposive random sampling technique. The instrumen used to essay test, kuesionerand observation. Based on result of this research, there is no impact between gender difference on critical thinking competence and metacognitive competence. Critical thinking aspect of male students belongs to equals category in 64,2 , critical thinking of female students belongs to equals category in 61,6. Metacognitive competence of male students to high category in 141, and metacognitivecompetence of female students to high category in 137. The percentage of total critical thinking competence of all students using PBL model in good and excellent category is $51 \%$, while the percentage of students' metacognitive competence in high category is $91 \%$.
\end{abstract}

Key words: critical thinking competence, metacognitive competence, genders difference, model of problem based learning

\begin{abstract}
Abstrak: Penelitian ini bertujuan untuk mengetahui profil kemampuan berpikir kritis dan kemampuan metakognitif siswa melalui model pembelajaran Problem Based Learning pada konsep pencemaran lingkungan di kelas X SMA Negeri 3 Kota Serang. Metode yang digunakan dalam penelitian ini adalah metode deskriptif. Populasi dalam penilitian ini adalah seluruh kelas X MIPA dengan sampel penelitian adalah X MIPA 5 SMA Negeri 3 Kota Serang yang berjumlah 43 orang. Teknik pengambilan sampel yang digunakan pada penelitian ini adalah purposive sampling. Instrumen dalam penelitian ini adalah tes esai kemampuan berpikir kritis, kuesioner kemampuan metakognitif, dan lembar observasi keterlaksanaan. Berdasarkan hasil penelitian dapat disimpulkan bahwa tidak adanya perbedaan kemampuan berpikir kritis dan kemampuan metakognitif siswa laki-laki dan perempuan. Rata-rata kemampuan berpikir kritis siswa laki-laki dan perempuan sebesar 64,2 dan 61,2 termasuk dalam kategori cukup. Kemampuan metakognitif siswa laki-laki dan perempuan memiliki nilai ratarata sebesar 141 dan 137 sehingga termasuk dalam kategori tinggi. Persentase total kemampuan berpikir kritis semua siswa menggunakan model PBL yang berada pada kategori baik dan sangat baik adalah $51 \%$, sedangkan persentase kemampuan metakognitif siswa pada kategori tinggi yaitu $91 \%$.
\end{abstract}

Kata kunci: kemampuan berpikir kritis, kemampuan metakognitif, model pembelajaran problem based learning, perbedaan jenis kelamin

Pendidikan merupakan unsur yang sangat penting dalam membangun sebuah negara. Pendidikan merupakan sebuah proses dengan metode-metode tertentu sehingga seseorang mampu memperoleh pengetahuan, pemahaman, dan cara bertingkah laku sesuai kebutuhan (Syah, 2010: 10). Permasalahan yang sering muncul dalam dunia pendidikan 
adalah lemahnya kemampuan siswa dalam menggunakan kemampuan berpikir kritisnya untuk menyelesaikan masalah dan mengelola kemampuan kognitifnya untuk merespon situasi atau permasalahan tersebut sehingga mencapai hasil belajar kognitif yang maksimal.

Menurut Wicaksono (2014: 85), pencapaian hasil belajar kognitif dalam pembelajaran biologi dapat berbeda antara satu siswa dengan siswa lainnya. Hal ini disebabkan oleh beberapa faktor diantaranya kemampuan berpikir kritis, kemampuan metakognitif, kemampuan akademik, strategi belajar, motivasi dan sebagainya. Diantara faktor-faktor tersebut, kemampuan berpikir kritis dan metakognitif memiliki peluang yang lebih besar dalam menjelaskan hasil belajar kognitif.

Berpikir kritis merupakan aktivitas terampil yang dilakukan untuk memenuhi standar kemampuan intelektual seperti kejelasan, relevansi, kecukupan, koherensi, dan lain sebagainya. Berpikir kritis menuntut adanya interpretasi dan evaluasi terhadap sumber-sumber informasi yang di dapat (Simamora, 2014: 2). Berpikir kritis dalam pembelajaran biologi sangat besar peranannya dalam meningkatkan proses, hasil belajar untuk bekal dimasa depan.Faktor lain yang mampu mempengaruhi hasil belajar kognitif yaitu kemampuan metakognitif. Dengan kemampuan metakognitif, siswa mampu mengetahui bagaimana mereka belajar, mengetahui kemampuan belajar yang dimiliki, serta mengetahui strategi belajar yang efektif untuk memperoleh hasil belajar yang optimal (Agustina \& Mulyanratna, 2012: 322).

Berdasarkan hasil observasi dan wawancara dengan guru biologi kelas $\mathrm{X}$ di SMA Negeri 3 Kota Serang, pembelajaran di kelas masih menekankan pada metode menghafal konsep. Peran siswa dalam pembelajaran masih kurang dan masih didominasi oleh guru sebagai pemberi informasi. Siswa kurang menunjukkan keaktifan dalam mengemukakan pendapatnya dan bertanya hanya ketika diminta oleh guru. Pertanyaan-pertanyaan yang diajukan oleh siswa belum menunjukkan pertanyaan kritis yang berkaitan dengan materi pembelajaran. Adapun dalam proses pembelajaran konsep pencemaran lingkungan, guru sudah menerapkan model pembelajaran seperti model Problem Based Learning, atau Project Based Learning, akan tetapi dalam evaluasinya siswa lebih banyak diminta untuk mengerjakan soal-soal latihan pada LKS dan buku paket. Konsep pencemaran lingkungan tidak bisa hanya sekedar ingatan mengenai konsep saja, tetapi siswa harus mampu menganalisis permasalahan sehingga mampu menyajikan solusi yang relevan.

Pemberdayaan kemampuan berpikir kritis dan metakognitif siswa dapat dilakukan dengan menerapkan model pembelajaran yang mampu merangsang kemampuan berpikir tingkat tinggi salah satunya yaitu model pembelajaran Problem Based Learning (PBL). Problem Based Learning (PBL) merupakan model pembelajaran yang mampu mengoptimalkan kemampuan berpikir siswa melalui proses kerja kelompok yang sistematis, sehingga mampu mengasah, dan mengembangkan kemampuan berpikirnya (Rusman, 2012: 229). Penelitian yang dilakukan Hartati dan Sholihin (2015: 505) menunjukkan bahwa model pembelajaran PBL dapat meningkatkan kemampuan berpikir kritis sebesar $47 \%$ pada kelas eksperimen dalam pembelajaran IPA di SMP. Begitu pula hasil penelitian Hadi (2009: 1) menyatakan bahwa siswa yang diajarkan dengan menggunakan strategi PBL pada pembelajaran matematika memiliki keterampilan metakognitif yang lebih baik 
daripada siswa yang diajar dengan strategi konvensional.

Kemampuan berpikir kritis dan kemampuan metakognitif siswa dapat diterapkan pada konsep biologi yang menuntut adanya pemecahan masalah yaitu konsep pencemaran lingkungan. Pada kurikulum 2013, konsep pencemaran lingkungan ini terdapat di kelas X KD 3.11. Siswa diminta untuk dapat menganalisis data perubahan lingkungan, penyebab, dan dampaknya bagi kehidupan. Penelitian yang mengukur kemampuan berpikir kritis dan metakognitif siswa di SMA Negeri 3 Kota Serang pada konsep pencemaran lingkungan belum pernah dilakukan, maka dari itu dirasa perlu dikaji secara lebih lanjut.

Berdasarkan permasalah tersebut, perlu dilakukan penelitian dengan judul "Profil Kemampuan Berpikir Kritis dan Kemampuan Metakognitif Siswa Berdasarkan Jenis Kelamin Melalui Model Pembelajaran Problem Based Learning Pada Konsep Pencemaran Lingkungan Kelas X SMA Negeri 3 Kota Serang”.

\section{METODE}

Metode yang digunakan dalam penelitian ini adalah metode deskriptif. Metode deskriptif merupakan metode penelitian yang berusaha menggambarkan atau menginterpretasikan objek sesuai dengan apa adanya (Sukardi, 2007: 157). Penelitian ini dilaksanakan pada semester genap tanggal 25 April sampai dengan $02 \mathrm{Mei}$ 2017 Tahun ajaran 2016/2017 di SMA Negeri 3 Kota Serang. Populasi dalam penelitian ini adalah siswa dan siswi SMA Negeri 03 Kota Serang kelas X MIPA tahun ajaran 2016-2017 sebanyak 7 kelas.

Sampel yang digunakan adalah kelas $\mathrm{X}$ MIPA 5 yang berjumlah 43 siswayaitu 19 siswa laki-laki dan 24 siswa perempuan.. Sampel ditentukan dengan menggunakan teknik purposive sampling. Teknik pengumpulan data dengan tes uraian kemampuan berpikir kritis, kuesioner kemampuan metakognitif,dan lembar observasi.

\section{PEMBAHASAN}

\section{Kemampuan Berpikir Kritis Siswa menggunakan Model Pembelajaran Problem Based Learning}

Kemampuan berpikir kritis siswa SMA Negeri 3 Kota Serang dinilai menggunakan tes uraian kemampuan berpikir kritis. Persentase kemampuan berpikir kritis siswa ditunjukkan pada gambar 1.

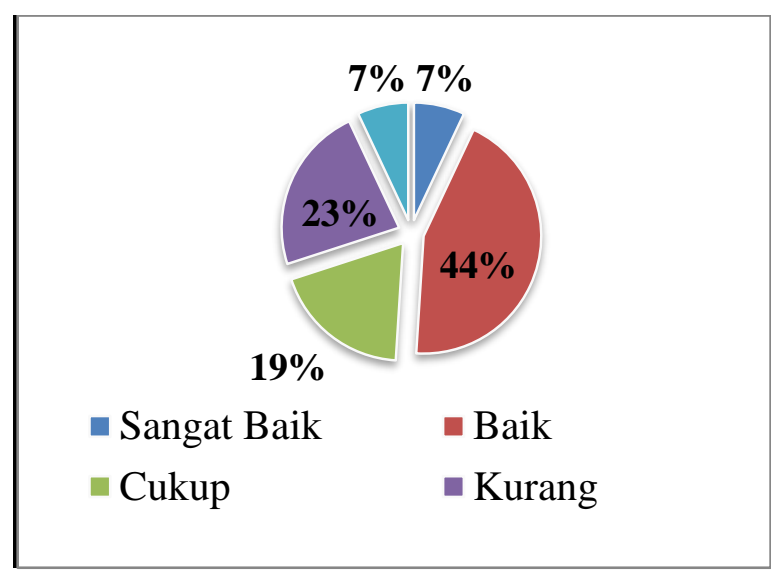

Gambar 1. Kemampuan berpikir kritis siswa melalui model pembelajaran problem based learning

Berdasarkan gambar 1, persentase total siswa yang memiliki kemampuan berpikir kritis sangat baik dan baik yaitu $51 \%$. Hal ini dikarenakan adanya penerapan model pembelajaran Problem Based Learning (PBL) yang diterapkan dalam proses belajar mengajar. Berdasarkan penilaian lembar observasi keterlaksanaan, model pembelajaran PBL ini $100 \%$ terlaksana dengan sangat baik. 22 orang siswa dengan kemampuan berpikir kritis sangat baik dan baik mampu mengikuti proses pembelajaran menggunakan model PBL dengan penuh 
konsentrasi, memperhatikan arahan guru, serta mengikuti diskusi dengan baik. Hal tersebut dapat dibuktikan dengan lembar kuesioner pernyataan positif yang terdapat pada nomor 24 yaitu "saya selalu mencoba memusatkan perhatian saya ketika dalam pembelajaran". 14 dari 22 orang siswa menyatakan bahwa mereka sering (SR) dan selalu (SE) mencoba memusatkan perhatiannya ketika sedang belajar. Begitupula pada kuesioner pernyataan negatif nomor 38 yang menyatakan "saya hanya menjadi pendengar saat diskusi", 18 siswa menjawab tidak pernah (TP) dan kadangkadang (K) Hal tersebut menunjukkan bahwa siswa-siswa tersebut mengikuti proses diskusi dengan aktif dan tidak hanya menjadi pendengar saja.

Jika siswa mampu mengikuti pembelajaran PBL dengan baik, maka siswa akan mampu memecahkan permasalahan dengan baik sehingga kemampuan berpikir kritis siswa dapat sangat baik, karena penerapan model PBL dalam pembelajaran mampu membantu siswa untuk dapat mengembangkan keterampilan berpikir kritis dan keterampilan menyelesaikan masalah (Sari, 2012: 13).

Persentase total siswa yang memiliki kemampuan berpikir kritis cukup, kurang dan sangat kurang yaitu 49\%. Hal tersebut dikarenakan rendahnya minat siswa untuk membaca permasalahan pada wacana pada saat menjawab soal ataupun pada saat kegiatan diskusi melalui model PBL, sehingga siswa tidak memahami permasalahan yang disajikan. Hal tersebut dapat dibuktikan dengan kuesioner pada penelitian ini juga yang memberikan pernyataan tentang minat membaca siswa yaitu pada pernyataan nomor 4 dan 5 . Pada pernyataan positif nomor 4 yaitu "Sebelum membuat rangkuman/ mengerjakan LKS pencemaran lingkungan, saya membaca berbagai sumber belajar seperti buku paket, internet, dan sebagainya.", dari 21 siswa yang memiliki kemampuan berpikir kritis cukup, kurang dan sangat kurang, hanya 5 orang siswa yang menjawab sering membaca untuk mengerjakan tugas, sedangkan pada pernyataan negatif nomor 5 yaitu "Saya mengerjakan rangkuman/ mengerjakan soal LKS pencemaran lingkungan hanya sesuai dengan pengetahuan saya tanpa membaca buku paket terlebih dahulu", hanya 7 orang siswa yang menjawab tidak pernah untuk tidak membaca buku sebelum mengerjakan tugas. Tentu saja hal tersebut dapat berdampak pada kurangnya kemampuan berpikir kritis siswa. Menurut Rinawati (2016: 24), "PBL hakikatnya dirancang untuk membantu siswa mengembangkan keterampilan berpikir dan mengembangkan kemampuan dalam memecahkan masalah". Pada pembelajaran dengan menggunakan model PBL, siswa dituntut untuk melakukan pemecahan masalah-masalah yang disajikan dengan cara menggali informasi sebanyakbanyaknya, kemudian dianalisis dan dicari solusi dari permasalahan yang ada. Jika siswa minat membacanya yang rendah, hal tersebut akan berpengaruh pada penggalian informasi yang harus didapatkan dalam sebuah wacana.

Kemampuan berpikir kritis juga masih perlu dilatihkan secara terus-menerus melalui latihan-latihan. Karena hanya dengan latihan, dapat membuat keterampilan berpikir kritis menjadi suatu kebiasaan. "Berpikir kritis merupakan sebuah kebiasaan berpikir yang seharusnya ditanamkan sejak usia dini, dan setiap orang memiliki potensi untuk menjadi pemikir kritis yang handal" (Lambertus, 2009: 140).

\section{Kemampuan Berpikir Kritis Siswa Berdasarkan Jenis Kelamin}

Jumlah siswa laki-laki pada kelas $\mathrm{X}$ MIPA 5 berjumlah 19 orang dan siswa 
perempuan berjumlah 24 orang. Adapun persentase kemampuan berpikir kritis siswa laki-laki dan perempuan dapat dilihat pada gambar 2.

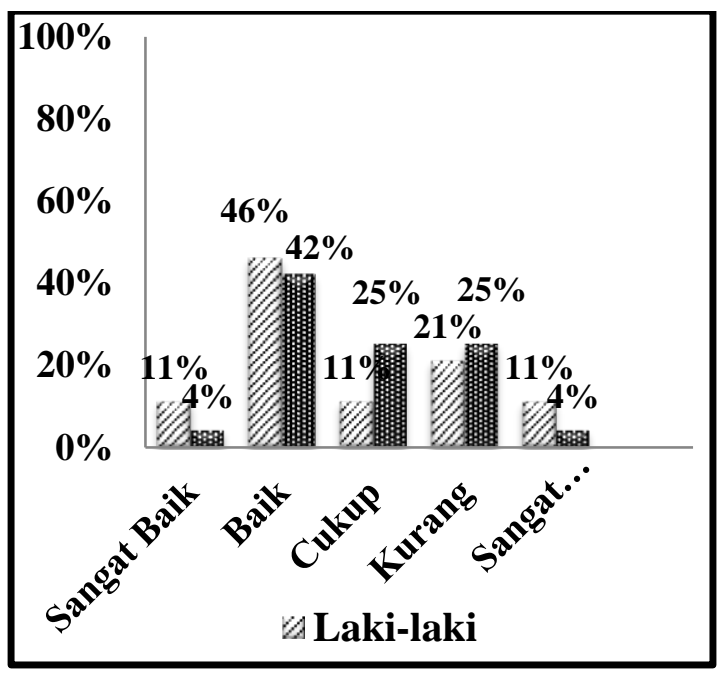

Gambar 2. Kemampuan berpikir kritis siswa laki-laki dan perempuan

Berdasarkan Gambar 2, dari 19 siswa laki-laki dan 24 siswa perempuan X MIPA 5, siswa laki-laki yang memiliki kemampuan berpikir kritis dengan kriteria sangat baik berjumlah 2 orang (11\%) sedangkan pada perempuan 1 orang (4\%). Siswa laki-laki yang memiliki kemampuan berpikir kritis dengan kriteria baik sebanyak 9 orang (46\%) dan pada perempuan sebanyak 10 orang (42\%). Perbandingan persentase kemampuan berpikir kritis pada kategori sangat baik dan baik siswa laki-laki lebih tinggi dibandingkan siswa perempuan. Berdasarkan hasil pengamatan yang dilakukan oleh tim observer dalam bentuk jurnal reflektif, selama proses pembelajaran siswa laki-laki lebih serius dalam belajar dan tidak banyak mengobrol dengan temannya dibandingkan dengan siswa perempuan, selain itu siswa laki-laki lebih mampu menjawab tes kemampuan berpikir kritis sesuai dengan jawaban yang diharapkan. Siswa laki-laki lebih mampu mengungkapkan solusi dari permasalahanpermasalahan yang diberikan pada soal karena siswa laki-laki memahami maksud pertanyaan yang diajukan. Pengamatan tersebut didukung dengan lembar kuesioner pernyataan positif nomor 34 yaitu "saya berusaha memahami maksud suatu pertanyaan sebelum menjawabnya", 11 dari 19 laki-laki (51\%) menjawab selalu (SE), sedangkan hanya 10 dari $24(41 \%)$ siswa perempuan yang menjawab selalu memahami maksud pertanyaan sebelum menjawabnya. Menurut Yogi (2015: 13) menyebutkan bahwa "perbedaan laki-laki dapat dihubungkan dengan tugas dan situasi". Lakilaki lebih baik dalam tugas-tugas yang terlihat maskulin seperti matematika dan sains dalam hal ini biologi, sedangkan perempuan lebih baik dalam tugas-tugas yang feminim seperti seni dan musik. Namun dalam kompetisi langsung antara laki-laki dan perempuan, ketika mulai memasuki masa dewasa, motivasi perempuan untuk mendapatkan prestasi menurun. Selain itu, inferior parietal otak sebelah kiri lebih besar pada laki-laki. Bagian itu sangat berfungsi dalam menyelesaikan tugastugas kognitif, terutama yang berhubungan dengan persepsi, dan proses visuospasial sehingga bisa saja siswa laki-laki mendapatkan nilai yang lebih tinggi dibandingkan perempuan dalam bidang sains.

Kriteria kemampuan berpikir kritis siswa laki-laki dengan kategori cukup 2 orang $(11 \%)$, pada siswa perempuan 6 orang $(25 \%)$, sedangkan kriteria kemampuan berpikir kritis laki-laki dengan kategori kurang 4 orang (21\%), pada siswa perempuan 6 orang $(25 \%)$. Kategori kemampuan berpikir kritis sangat kurang 2 orang (11\%), sedangkan pada siswa perempuan 1 orang (4\%). Cukup, kurang dan sangat kurangnya kemampuan berpikir kritis siswa laki-laki maupun siswa perempuan dikarenakan siswa-siswa tersebut kurang memperhatikan materi yang belum mereka pahami dalam pembelajaran, sehingga mereka merasa kesulitan dalam pengerjaan 
soal. Selain itu, siswa kurang bisa mengaitkan pengetahuan yang relevan yang dapat membantu untuk menjawab soal. Hal ini dapat dibuktikan dengan lembar kuesioner pada pernyataan nomor 14 yaitu "saya kurang memperhatikan materi yang belum atau yang sudah saya pahami dalam pembelajaran biologi”. 21 siswa yang memiliki kemampuan berpikir kritis cukup, kurang, dan sangat kurang, hanya 1 siswa laki-laki dan 3 siswa perempuan yang tidak pernah (TP) untuk kurang memperhatikan materi yang belum dipahami dalam belajar. Begitupula pada kuesioner pernyataan nomor 48 yang menyatakan "saya tidak pernah mengaitkan pengetahuan yang saya miliki dengan materi pembelajaran yang sedang berlangsung", hanya 1 siswa laki-laki dan 2 siswa perempuan yang tidak pernah (TP) untuk tidak mengaitkan pengetahuan yang mereka miliki dengan materipembelajaran yang berlangsung.

Rata-rata kemampuan berpikir kritis siswa laki-laki sebesar 64,2 (kategori cukup) sedangkan nilai rata-rata kemampuan berpikir kritis pada siswa perempuan yaitu 61,6 (kategori cukup). Data rata-rata kemampuan berpikir kritis laki-laki dan perempuan dapat dilihat pada lampiran 16. Persentase rata-rata kemampuan berpikir kritis dapat dilihat pada gambar 3 .

Berdasarkan gambar 3 menunjukkan bahwa kemampuan rata-rata siswa laki-laki dan siswa perempuan berada pada kriteria cukup, sehingga kemampuan berpikir kritis siswa laki-laki dan perempuan tidak jauh berbeda. Penemuan ini sejalan dengan penelitian yang dilakukan oleh Myers (2006: 1), menunjukkan bahwa "tidak ada perbedaan yang nyata kemampuan berpikir kritis antara siswa laki-laki dan perempuan". Sama hal nya dengan penelitian yang dilakukan Prambudiono (2012: 5) bahwa "tidak ada perbedaan secara signifikan dalam aspek kemampuan berpikir pada siswa laki-laki dan siswa perempuan". Penelitian ini juga didukung oleh hasil wawancara yang dilakukan dengan guru biologi kelas $\mathrm{X}$ di SMA Negeri Kota Serang yang menyebutkan bahwa tidak ada perbedaan kemampuan belajar siswa dalam hal ini kemampuan berpikir kritis antara siswa laki-laki dan siswa perempuan.

$$
\begin{array}{r}
100 \\
80 \\
60 \\
40 \\
20 \\
0 \\
\text { Laki-laRèrempuan }
\end{array}
$$

Gambar 3. Rata-rata kemampuan berpikir kritis siswa laki-laki dan perempuan

Temuan ini bertentangan dengan penelitian yang dilakukan Mahanal (2012: 182) yang menyatakan bahwa "siswa laki-laki dan perempuan memiliki kemampuan berpikir kritis yang berbeda". Siswa perempuan memiliki kemampuan bepikir kritis lebih tinggi dibandingkan dengan siswa laki-laki. Pada penelitian Mahanal, siswa Perempuan mendapatkan nilai tinggi pada aspek membuat membuat kesimpulan, menyusun hipotesis, dan mempertimbangkan informasi yang relevan. Menurut Mahanal, pada perempuan daerah otak yang berhubungan dengan fungsi bahasa bekerja lebih keras yang mengakibatkan kemampuan bahasa perempuan lebih tinggi dibanding laki-laki. Bahasa merupakan alat yang digunakan untuk menyampaikan pikiran. Kemampuan penggunakaan bahasa yang bagus merupakan indikator kemampuan berpikir tinggi. 
Kemampuan berpikir kritis yang sama antara siswa laki-laki dan siswa perempuan juga dapat diakibatkan siswa perempuan belum bisa mengoptimalkan kemampuan berbahasa mereka, karena pada dasarnya bahasa merupakan alat untuk mengungkapkan ide-ide atau pendapat sehingga dapat digunakan untuk penyelesaian sebuah masalah yang berhubungan dengan proses berpikir kritis. Nurdin (2009: 69) mengatakan bahwa "perempuan sebenarnya memiliki kemampuan berbahasa yang lebih baik dibandingkan laki-laki karena memiliki saraf penghubung yang tebal antara otak kanan dan otak kirinya". Jika siswa perempuan tidak bisa mengoptimalkan kemampuan berbahasanya, sedangkan siswa laki-laki berusaha untuk mengembangkan kemampuannya bahasanya, maka siswa lakilaki kemungkinan besar dapat mengimbangi kemampuan berpikir kritis siswa perempuan.

Kemampuan berpikir kritis siswa diukur berdasarkan 4 indikator, yaitu klarifikasi, asesmen, inferensi, dan strategi. Perolehan nilai rata-rata kemampuan berpikir kritis setiap indikator ditunjukkan pada Gambar 4.

\section{Klarifikasi}

Indikator klarifikasi ini meminta siswa untuk dapat merumuskan masalah dengan tepat dan jelas. Rata-rata nilai indikator klarifikasi pada siswa laki-laki adalah 75 , dan siswa perempuan memiliki rata-rata 68 dan berada pada kategori baik. Guru memberikan tes uraian mengenai gambar pencemaran lingkungan yaitu pencemaran air akibat sampah dan akibat limbah untuk dianalisis oleh siswa. Indikator ini merupakan indikator kemampuan berpikir kritis yang memiliki nilai paling tinggi diantara indikator-indikator kemampuan berpikir kritis lainnya. Hal ini dikarenakan gambar pencemaran lingkungan sudah sering dilihat pada kehidupan mereka sehari-hari, sehingga mereka mampu merumuskan atau menganalisis permasalahan yang terjadi.

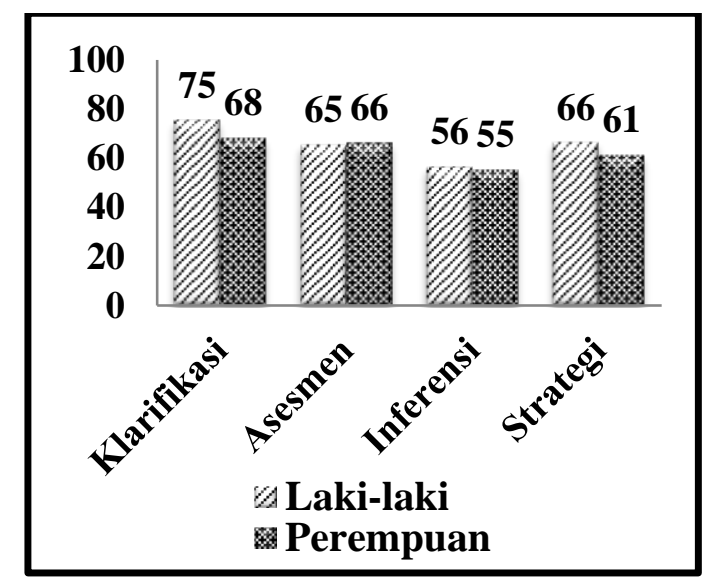

Gambar 4. Kemampuan berpikir kritis siswa laki-laki dan perempuan pada setiap indikator

\section{Klarifikasi}

Indikator klarifikasi ini meminta siswa untuk dapat merumuskan masalah dengan tepat dan jelas. Rata-rata nilai indikator klarifikasi pada siswa laki-laki adalah 75 , dan siswa perempuan memiliki rata-rata 68 dan berada pada kategori baik. Guru memberikan tes uraian mengenai gambar pencemaran lingkungan yaitu pencemaran air akibat sampah dan akibat limbah untuk dianalisis oleh siswa. Indikator ini merupakan indikator kemampuan berpikir kritis yang memiliki nilai paling tinggi diantara indikator-indikator kemampuan berpikir kritis lainnya. Hal ini dikarenakan gambar pencemaran lingkungan sudah sering dilihat pada kehidupan mereka sehari-hari, sehingga mereka mampu merumuskan atau menganalisis permasalahan yang terjadi.

Selain itu, kemampuan klarifikasi juga dilatihkan ketika siswa mengerjakan LKS tentang pencemaran lingkungan. Perolehan nilai rata-rata indikator siswa laki- 
laki lebih besar dibandingkan siswa perempuan dikarenakan siswa laki-laki lebih fokus dalam belajar dan mendengarkan arahan guru pada saat menjelaskan soal gambar pencemaran lingkungan, sedangkan siswa perempuan kurang memperhatikan dalam pembelajaran dan lebih banyak mengobrol dengan temannya sehingga siswa perempuan kurang fokus dalam belajar sehingga siswa perempuan kurang memahami maksud soal. Hal tersebut didukung oleh hasil pengamatan yang dilakukan oleh tim observer, jurnal reflektif peneliti, dan kuesioner pada pernyataan nomor 24 yaitu "saya mencoba memusatkan perhatian saya ketika dalam pembelajaran", hanya 7 dari 24 siswa perempuan yang menjawab selalu (SE) memusatkan perhatian ketika dalam pembelajaran.

\section{Asesmen}

Indikator asesmen meminta siswa untuk dapat membuat pertanyaan dari wacana, dan menjawab pertanyaan yang jawabannya berada pada wacana. Rata-rata nilai indikator asesmen siswa laki-laki adalah 65 tergolong pada kategori cukup, sedangkan siswa perempuan 66 berada pada kategori baik. Guru memberikan wacana mengenai dampak dari pencemaran lingkungan yaitu efek rumah kaca, hujan asam, dan global warming. Perolehan nilai indikator asesmen pada perempuan lebih besar dibandingkan dengan siswa laki-laki. Hal ini dikarenakan siswa perempuan secara umum lebih unggul dalam bahasa dan menulis, sedangkan siswa laki-laki lebih unggul dalam matematika karena kemampuan-kemampuan ruangnya yang lebih baik. Sehingga siswa perempuan mampu membuat pertanyaan yang sesuai dengan wacana yang disajikan (Wijayanti, 2013: 6).

\section{Inferensi}

Indikator inferensi menuntut siswa untuk dapat membuat kesimpulan yang tepat dari wacana. Indikator kemampuan berpikir kritis inferensi siswa laki-laki memiliki ratarata 56 dan tergolong kategori cukup, sedangkan pada siswa perempuan memiliki rata-rata 55 dan tergolong kategori rendah. Inferensi merupakan indikator dengan nilai paling rendah di antara indikator-indikator kemampuan berpikir kritis lainnya. Hal ini terjadi karena banyak siswa kurang mencermati permasalahan yang terjadi pada wacana karena rendahnya minat baca siswa terhadap soal yang diberikan, akibatnya kesimpulan yang dibuat oleh siswa kurang sesuai dengan yang diharapkan.

\section{Strategi}

Rata-rata nilai yang diperoleh siswa laki-laki pada indikator kemampuan berpikir kritis strategi adalah 66 dan berada pada kategori baik. Sedangkan pada siswa perempuan nilai rata-ratanya 61 dan berada pada kategori cukup. Pada indikator ini siswa diminta untuk dapat berpikir terbuka dalam menyelesaikan masalah. Siswa harus memikirkan strategi yang tepat berdasarkan permasalahan yang diberikan. Dalam tes uraian, siswa diminta untuk dapat menyajikan solusi yang tepat untuk menangani masalah kebakaran hutan dan masalah pembuang sampah sembarangan. Indikator strategi ini juga dilatihkan ketika siswa mengerjakan LKS pencemaran lingkungan bersama kelompoknya. Perolehan nilai rata-rata siswa laki-laki lebih tinggi daripada siswa perempuan. Hal ini dikarenakan ketika menjawab soal, siswa laki-laki lebih kreatif dalam mengungkapkan gagasannya dalam menyajikan solusi yang relevan. Penemuan ini tidak sejalan dengan pendapat Mahanal (2012: 182) yang mengemukakan bahwa secara konsisten perempuan menunjukkan kelebihan dalam kemampuan verbal, lebih 
ekspresif, dan lebih kaya kosakata dibandingkan laki-laki.

\section{Kemampuan Metakognitif Siswa Melalui Model Pembelajaran Problem Based Learning}

Kemampuan

metakognitif

(kemampuan berpikir tingkat tinggi) siswa

di kelas X MIPA 5 SMA Negeri 3 Kota

Serang diukur dengan menggunakan lembar

kuesioner kemampuan metakognitif berjumlah 49 pernyataan. Persentase kemampuan metakognitif siswa ditunjukkan pada gambar 5 .

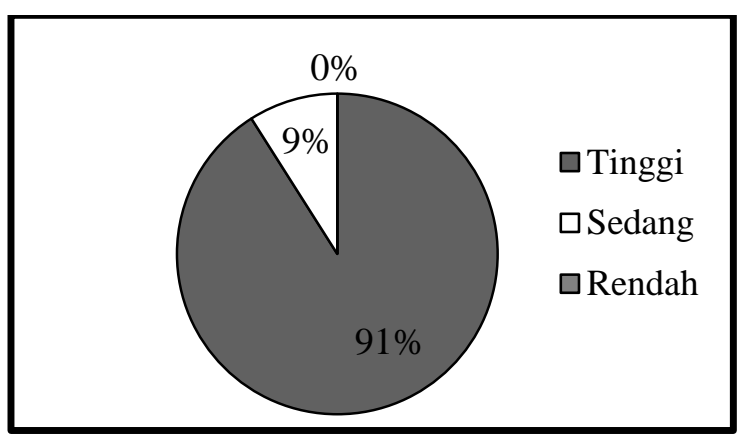

Gambar 5. Kemampuan metakognitif siswa melalui model problem basedlearning

Berdasarkan gambar $4.5,91 \%$ siswa $\mathrm{X}$ MIPA 5 memperoleh nilai kemampuan metakognitif pada kategori tinggi. Tingginya kemampuan metakognitif siswa dikarenakan penggunaan model pembelajaran yang mampu mengembangkan kemampuan berpikir tingkat tinggi siswa salah satunya yaitu model pembelajaran Problem Based Learning (PBL). Menurut Danial (2010: 9) "PBL adalah sebuah model pembelajaran yang titik awal pembelajaran berdasarkan masalah dalam kehidupan nyata, lalu dari masalah ini siswa dirangsang untuk mempelajari masalah berdasarkan pengetahuan dan pengalaman yang telah mereka punyai sebelumnya", sehingga akan terbentuk pengetahuan dan "pengalaman baru dan secara signifikan akan meningkatkan kemampuan metakognitif siswa" (Sastrawati, 2011: 3).

Potensi pembelajaran PBL dalam memberdayakan kemampuan metakognitif siswa tidak terlepas dari peran sintaks model pembelajaran tersebut. Sintaks pertama model PBL yaitu kegiatan pemberian masalah pada LKS pencemaran lingkungan. Dengan diberikan masalah, siswa akan secara otomatis merencanakan diri untuk mengerjakan soal dan mencari strategi belajar yang tepat untuk mencarikan solusi permasalahan. Sintaks selanjutnya yaitu siswa melakukan diskusi dan melakukan kajian. ketika berdiskusi dan melakukan kajian dengan teman kelompoknya, siswa akan berusaha berpikir untuk menjawab pertanyaan pada LKS dengan baik secara mandiri maupun secara kelompok. Kegiatan berpikir untuk menjawab pertanyaan dapat melatih keterampilan perencanaan diri dan pemantauan diri yang merupakan salah satu bagian dari kemampuan metakognitif. Menurut King (dalam Syarifah, 2016: 803) berpendapat bahwa "berdiskusi untuk memprediksikan jawabannya akan berfungsi sebagai strategi metakognitif, membantu siswa untuk lebih memerhatikan proses penyelesaian masalah, memonitor perkembangannya, dan mendorong keberhasilan dalam memecahkan masalahnya". Dengan membuat pertanyaan dan jawaban secara mandiri, siswa menjadi lebih menyadari akan hasil belajar yang diperolehnya. Tahapan selanjutnya adalah melakukan tukar informasi, menyajikan solusi dan melakukan evaluasi dengan cara mempresentasikan hasil diskusi. Pada saat menyajikan solusi dan tukar informasi di depan kelas, siswa dapat saling memonitor dan mengevaluasi hasil pemikiran mereka pada saat diskusi dan presentasi di dalam kelas. Kemampuan siswa dalam memantau dan mengevaluasi hasil pemikirannya 
merupakan suatu kemampuan metakognitif. Selain itu, guru juga memberikan tugas kepada siswa untuk membuat rangkuman pembelajaran. Hal ini dimaksudkan agar siswa mampu memantau pengetahuan, dan menyadari apa yang ia pelajari untuk membantu mengembangkan kemampuan metakognitif.

\section{Kemampuan Metakognitif Siswa Berdasarkan Jenis Kelamin}

Hasil penelitian menunjukkan bahwa sebanyak 95\% siswa laki-laki memiliki kemampuan metakognitif dengan kategori tinggi. Sedangkan $88 \%$ siswa perempuan juga dalam kategori tinggi. Secara lengkap persentasi kemampuan metakognitif dapat dilihat pada gambar 6 .

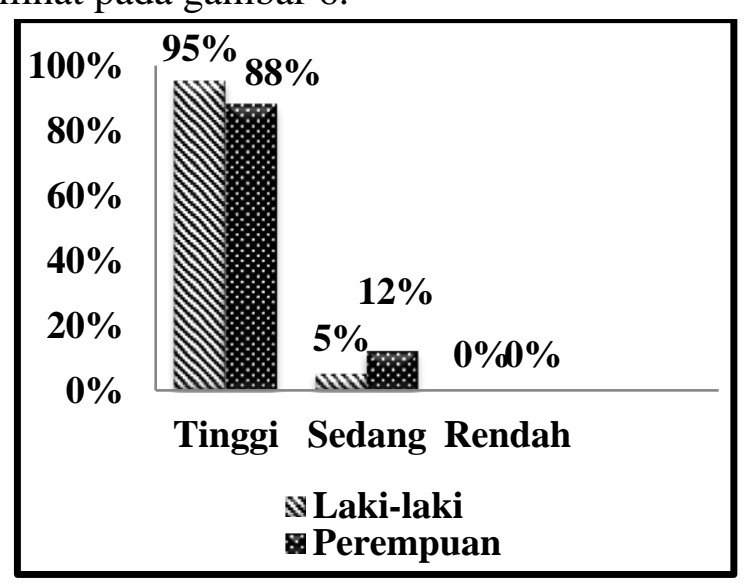

Gambar 6. Kemampuan metakognitif siswa laki-laki dan perempuan

Berdasarkan gambar 6, dari 19 siswa laki-laki, 18 siswa (95\%) diantaranya memiliki kemampuan metakognitif dengan kategori tinggi, 1 orang $(5 \%)$ yang memiliki kemampuan metakognitif sedang dan tidak ada yang memiliki kemampuan metakognitif kategori rendah. Pada siswa perempuan yang berjumlah 24 orang, 21 siswa ( $88 \%$ ) memiliki kemampuan metakognitif dengan kategori tinggi, 3 orang (12\%) memiliki kemampuan metakognitif dengan kategori sedang, dan tidak ada yang memiliki kemampuan metakognitif kategori rendah. Tidak adanya siswa yang memiliki kemampuan metakognitif rendah karena kemampuan metakognitif sebenarnya telah berkembang sejak masa anak-anak awal dan terus berlanjut sampai usia sekolah dasar dan seterusnya hingga pada puncaknya yaitu pada tahapan operasi formal (12 tahun).

Pada usia sekolah dasar seiring dengan tuntutan kemampuan kognitif yang harus dikuasai oleh siswa, mereka dituntut pula untuk dapat menggunakan dan mengatur kognitif mereka. "Metakognitif banyak digunakan dalam situasi pembelajaran, seperti dalam menyelesaikan soal pemecahan masalah matematika, membaca buku, serta dalam melakukan kegiatan drama atau bermain peran" (Lidinillah, 2007: 4). Kemampuan metakognitf anak tidak muncul dengan sendirinya, tetapi memerlukan latihan sehingga menjadi kebiasaan. Suherman (dalam Lidinillah, 2007: 5) menyatakan bahwa "perkembangan metakognitif dapat diupayakan melalui cara dimana anak dituntut untuk mengobservasi tentang apa yang mereka ketahui dan kerjakan, dan untuk merefleksi tentang apa yang dia observasi, oleh karena itu, sangat penting bagi guru atau pendidik (termasuk orang tua) untuk mengembangkan kemampuan metakognitif baik melalui pembelajaran ataupuan mengembangkan kebiasaan di rumah.

Data rata-rata kemampuan metakognitif laki-laki dan perempuan terdapat pada lampiran 11. Persentase rata-rata kemampuan metakognitif dapat dilihat pada gambar 7 . 


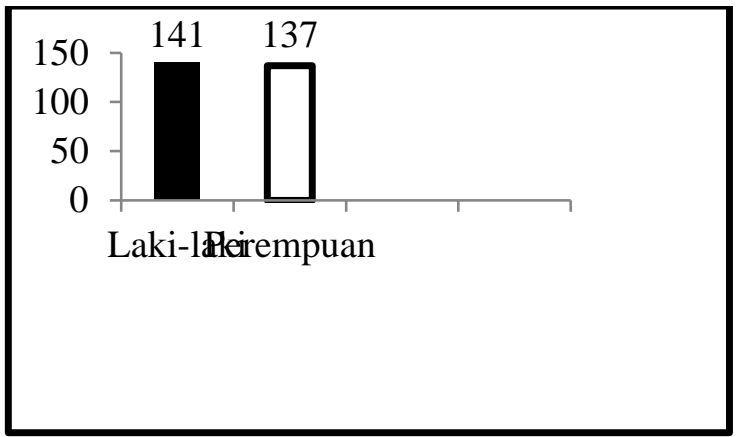

\section{Gambar 7. Rata-rata kemampuan metakognitif siswa}

Rata-rata kemampuan metakognitif siswa laki-laki yaitu 141 berada pada kategori tinggi dan nilai rata-rata siswa perempuan 137 dan berada pada kategori tinggi pula, sehingga kemampuan metakognitif siswa laki-laki dan perempuan tidak jauh berbeda. Penemuan tersebut sejalan pula dengan penelitian yang dilakukan oleh Brasilita (2015: 6), yang menyatakan bahwa "jenis kelamin tidak berpengaruh terhadap kemampuan metakognitif". Kemampuan metakognitif antara siswa laki-laki dan perempuan tidak berbeda nyata. Hasil ini menunjukkan bahwa antara jenis kelamin perempuan dan laki-laki memiliki sumbangan yang sama dalam memberdayakan kemampuan metakognitif.

Tidak adanya perbedaan kemampuan metakognitif berdasarkan Jenis kelamin ini dapat dikarenakan penggunaan model pembelajaran PBL yang diterapkan mampu meminimalisir perbedaan jenis kelamin pada saat pembelajaran, sehingga siswa laki-laki dan perempuan dapat mencapai kemampuan metakognitif yang setara. Penemuan ini juga sesuai dengan hasil wawancara di SMA Negeri 3 Kota Serang bahwa antara siswa laki-laki dan perempuan memiliki kemampuan belajar yang sama. Berdasarkan lembar kuesioner yang diisi oleh siswa kelas $X$ MIPA 5 SMA Negeri 3 Kota Serang, siswa laki-laki dan perempuan memiliki kemampuan merencanakan tujuan belajar, memonitor proses belajar, dan mengevaluasi hasil belajarnya yang relatif sama, perbedaan keduanya tidak begitu menonjol.

Temuan ini tidak sejalan dengan penelitian yang dilakukan oleh Nurmaliah (2009: 20) yang menunjukkan bahwa "ratarata kemampuan metakognitif siswa perempuan lebih tinggi dari siswa laki-laki”. Hal ini menunjukkan siswa perempuan lebih mampu dalam berpikir dan mengatur cara berpikirnya sehingga hasil belajar juga akan lebih tinggi. Penelitian Nurmaliah menunjukkan bahwa "siswa perempuan lebih tekun dan berkonsentrasi, sedangkan siswa laki-laki lebih banyak bermain". Demikian juga hasil pengamatan selama kegiatan pembelajaran biologi, siswa perempuan lebih serius dalam melakukan pengamatan, banyak bertanya, berani dalam mempresentasikan baik hasil pengamatan maupun dalam kegiatan diskusi. Hasil penelitian dari Syarifah (2016: 804) juga mengatakan bahwa "terdapat perbedaan jenis kelamin terhadap kemampuan metakognitif”.

Kemampuan metakognitif siswa lakilaki dan siswa perempuan diukur berdasarkan 4 indikator, yaitu perencanaan diri, pemantauan diri, strategi kognitif, dan kesadaran diri diukur dengan menggunakan lembar kuesioner kemampuan metakognitif yang berisi pernyataan positif dan negatif. Kuesioner tersebut siswa diminta untuk memilih 1 skala penilaian yaitu tidak pernah, sering, kadang-kadang, dan selalu. Perhitungan secara lengkap perolehan nilai kemampuan metakognitif siswa. Perolehan nilai rata-rata kemampuan metakognitif siswa setiap indikator ditunjukkan pada gambar dibawah ini. 


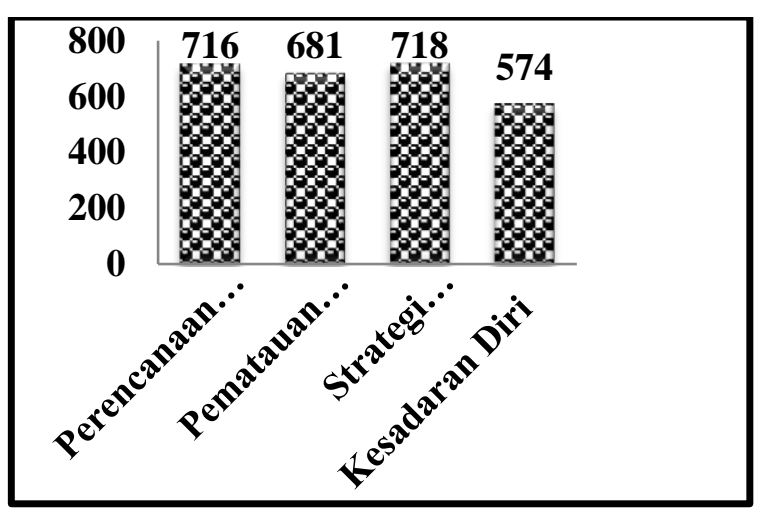

Gambar 8. Kemampuan metakognitif siswa laki-laki pada setiap indikator

Berdasarkan gambar 8, menunjukkan bahwa perolehan nilai kemampuan metakognitif siswa laki-laki pada semua indikator berada pada kategori tinggi. Hal ini mengartikan bahwa siswa laki-laki sudah bisa mengembangkan kemampuan metakognitifnya dengan baik.

Perolehan nilai kemampuan metakognitif pada siswa perempuan dapat diihat pada gambar 9 .

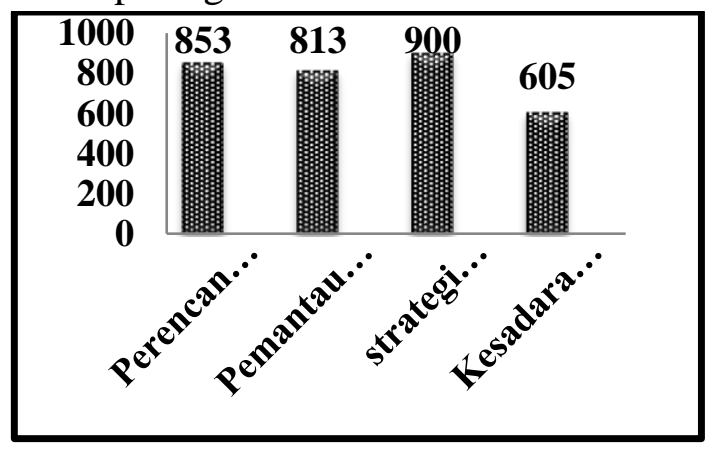

Gambar 9. Kemampuan metakognitif siswa perempuan pada setiap indikator

Berdasarkan gambar 9 menunjukkan bahwa kemampuan metakognitif siswa perempuan pada semua indikator berada pada kategori tinggi. Tidak berbeda dengan kemampuan metakognitif siswa laki-laki, siswa perempuan juga sudah bisa mengelola kemampuan metakognitif dengan baik.

Tingginya semua indikator kemampuan metakognitif di kelas X MIPA 5 SMA Negeri 3 Kota Serang dapat disebabkan mereka merupakan siswa yang mendapatkan situasi, lingkungan baru, dan kebiasaan belajar yang berbeda dengan ketika mereka masih di Sekolah Menengah Pertama (SMP) sehingga mereka lebih mengikuti aturan yang berlaku di sekolah. Kebiasaan belajar yang baru ini dipengaruhi oleh lingkungan yaitu teman-teman yang baru mereka kenal, sehingga mereka lebih serius dalam belajar dan mengerjakan tugas yang diberikan oleh guru. Penjelasan lebih lanjut mengenai indikator kemampuan kemampuan metakognitif yaitu:

\section{Perencanaan Diri}

Indikator perencanan diri pada lembar kuesioner terdapat pada pernyataan nomor 12 , $13,21,33,1,2,40,45,46,4,29,44$, dan 5 yang terdiri dari 7 pernyataan positif dan 6 pernyataan negatif (lampiran 8). Pada indikator ini siswa menyadari tujuan dalam belajar, mengatur waktu untuk menyelesaikan tugas belajar, dan mengetahui pengetahuan yang relevan untuk menyelesaikan masalah. Pada siswa laki-laki perolahan nilai paling tinggi yaitu 65 terdapat pada pernyataan nomor 33 dengan pernyataan negatif "saya belajar tanpa menentukan tujuan saya belajar". 13 siswa laki-laki memilih opsi tidak pernah, sehingga kebanyakan siswa memperoleh nilai 4. Hal ini menunjukkan bahwa kebanyakan siswa belajar selalu memiliki tujuan. Sedangkan pada siswa perempuan, perolehan nilai tertinggi juga terdapat pada nomor 33 .

\section{Pemantauan Diri}

Indikator pemantauan diri pada lembar kuesioner terdapat pada pernyataan nomor 3 , $25,9,10,37,22,28,14,15,30,43,31,42$ yang terdiri dari 7 pernyataan positif dan 6 pernyataan negatif. Pada indikator ini siswa harus menyadari pemantauan ketercapaian tujuan, pemantauan waktu yang digunakan, dan pemantauan pengetahuan awal dengan 
materi pembelajaran. Pada siswa laki-laki perolahan nilai paling tinggi pada indikator ini yaitu 60 terdapat pada pernyataan nomor 22 dengan pernyataan positif "saya berpendapat bahwa pengetahuan yang telah saya peroleh pada saat teori dapat membantu mengerjakan rangkuman atau LKS pencemaran lingkungan". 8 siswa memilih opsi sering (SR) sehingga kebanyakan siswa memperoleh nilai 3. Hal ini menunjukkan bahwa kebanyakan siswa menyadari bahwa pengetahuan yang mereka peroleh dapat membantu mengerjakan tugas. Sedangkan pada siswa perempuan, perolehan nilai tertinggi yaitu 77 terdapat pada nomor 15 dengan pernyataan negatif yaitu "saya membiarkan saja kesulitan yang saya temukan dalam belajar". 11 siswa perempuan memilih opsi tidak pernah (TP) sehingga kebanyakan memperoleh nilai 4. Hal ini menunjukkan bahwa siswa perempuan tidak pernah membiarkan kesulitan yang ia temui ketika sedang belajar.

\section{Strategi Kognitif}

Indikator strategi kognitif pada lembar kuesioner terdapat pada pernyataan nomor 34, $36,24,41,8,32,35,27,20,38,39,18$, 26yang terdiri dari 8 pernyataan positif dan 5 pernyataan negatif. Pada indikator ini siswa harus menyadari strategi-strategi kognitif yang digunakan untuk belajar dan strategi untuk mengevalusi hasil belajar mereka. Pada siswa laki-laki perolahan nilai paling tinggi pada indikator ini yaitu 62 terdapat pada pernyataan nomor 27 dengan pernyataan positif "saya memeriksa kembali hasil pekerjaan saya dalam tes atau ulangan". 10 siswa memilih opsi selalu (SE) sehingga kebanyakan siswa memperoleh nilai 4. Hal ini menunjukkan bahwa kebanyakan siswa lakilaki selalu memeriksa jawaban ulangan mereka sebelum dikumpulkan. Sedangkan pada siswa perempuan, perolehan nilai tertinggi terdapat pada nomor 26 yaitu 78 dengan pernyataan negatif yaitu "saya tidak memperbaiki kesalahan dalam belajar biologi”. Rata-rata siswa perempuan memilih opsi tidak pernah (TP) sehingga kebanyakan memperoleh nilai 4. Hal ini menunjukkan bahwa siswa perempuan selalu memperbaiki kesalahan dalam belajar biologi.

\section{Kesadaran Diri}

Indikator kesadaran diri pada lembar kuesioner terdapat pada pernyataan nomor 7 , $49,47,48,23,11,16,17,6$ yang terdiri dari 5 pernyataan positif dan 5 pernyataan negatif. Pada indikator ini siswa harus menyadari persiapan untuk belajar, menyadari strategi yang tepat untuk belajar, dan menyadari pengetahuan yang diperlukan dalam pembelajaran. Pada siswa laki-laki perolahan nilai paling tinggi pada indikator ini yaitu 62 terdapat pada pernyataan nomor 7 dengan pernyataan positif "saya memahami butuh perencanaan dalam belajar". 8 siswa memilih opsi selalu (SE) sehingga kebanyakan siswa memperoleh nilai 4. Hal ini menunjukkan bahwa kebanyakan siswa laki-laki memahami perencanaan dalam setiap belajar, sedangkan pada siswa perempuan, perolehan nilai tertinggi terdapat pada nomor 48 yaitu 77 dengan pernyataan negatif yaitu "saya tidak pernah mengaitkan pengetahuan yang saya punya dengan materi pelajaran yang sedang berlangsung.". Rata-rata siswa perempuan memilih opsi tidak pernah (TP) sehingga kebanyakan memperoleh nilai 4. Hal ini menunjukkan bahwa siswa perempuan selalu mengaitkan pengetahuan yang ia miliki dengan materi pembelajaran yang berlangsung.

\section{Kemampuan Berpikir Kritis, Kemampuan Metakognitif, dan Jenis Kelamin dalam Pembelajaran Biologi}


Pembelajaran ideal merupakan pembelajaran yang mampu membantu siswa untuk mencapai kompetensi yang diharapkan. Pembelajaran biologi didalamnya banyak termuat kegiatan eksplorasi yang pada dasarnya mampu untuk meningkatkan kompetensi siswa. Salah satu kompetensi yang diharapkan dimiliki oleh siswa dalam pembelajaran biologi ialah hasil belajar kognitif. Pencapaian hasil belajar kognitif dalam pembelajaran Biologi dapat berbeda antara satu siswa dengan siswa lainnya. Hal ini disebabkan adanya beberapa variabel yang dapat mempengaruhi hasil belajar kognitif siswa, diantaranya yaitu kemampuan metakognitif, berpikir kritis, kemampuan akademik, strategi belajar, motivasi dan sebagainya. Diantara variabel tersebut, "kemampuan metakognitif dan berpikir kritis memiliki peluang yanglebih besar dalam menjelaskan hasil belajar kognitif" (Wicaksono, 2014: 85). Kemampuan berpikir kritis dan kemampuan metakognitif harus dilatih dan dikembangkan dalam proses pembelajaran karena sangat bermanfaat bagi siswa. Kemampuan berpikir kritis akan membantu siswa melihat potensi diri, sehingga mereka sudah terlatih menyelesaikan berbagai persoalan yang dihadapi, termasuk melihat sejauh mana kemampuan yang mereka miliki, sehingga akan berdampak pada pencapaian prestasi belajar yang optimal. Selain itu, Menurut Kusmijati (2012: 3) "kondisi dunia yang semakin berkembang pesat menuntut siswa memiliki kemampuan berpikir kritis untuk menjawab berbagai tantangan global yang ada". Siswa tidak hanya dituntut untuk mampu menyelesaikan tugas, ataupun mendapatkan nilai yang baik, tetapi siswa juga dituntut untuk memiliki kemampuan berpikir kritis, sehingga siswa dapat memutuskan mana yang benar dan salah, mana yang perlu diikuti dan ditinggalkan agar tidak ikut terseret arus globalisasi. Kemampuan berpikir kritis juga bermanfaat dalam penyelesaian masalah individu maupun masalah sosial yang terjadi di masyarakat. Seseorang yang memiliki kemampuan berpikir kritis akan mampu menyelesaikan masalah dengan tepat dan tidak menimbulkan masalah baru karena adanya pertimbangan dari berbagai sisi.

Kemampuan metakognitif perlu dikembangkan dalam pembelajaran biologi karena siswa yang menggunakan kemampuan metakognitif dalam belajar memiliki prestasi yang lebih baik karena kemampuan metakognitif memungkinkan siswa untuk melakukan perencanaan, mengikuti perkembangan, dan memonitor proses belajarnya. Dengan kemampuan metakognitif, siswa mampu memahami dan mengatur lingkungan belajar sehingga jika kemampuan metakognitifnya bagus maka dapat berdampak pula pada meningkatkan hasil belajar kognitifnya. Kemampuan metakognitif sangat diperlukan untuk kesuksesan belajar, karena "dengan metakognisi memungkinkan siswa untuk mampu mengelola kecakapan kognisi dan mampu menemukan kelemahannya yang akan diperbaiki dengan kecakapan kognisi berikutnya" (Brasilita, 2015: 3).

Seperti kita tahu, bahwa kemampuan berpikir kritis dan kemampuan metakognitif dapat meningkatkan hasil belajar biologi. Kemampuan berpikir kritis dan kemampuan metakognitif siswa dalam pembelajaran tidak dapat dibedakan berdasarkan jenis kelamin jika situasi tidak memungkinkan, dalam hal ini siswa laki-laki mampu mengimbangi kemampuan yang dimiliki oleh siswa perempuan. Sebagai seorang guru dalam menyikapi hal tersebut, guru dalam pembelajaran harus meminimalisir perbedaan jenis kelamin dengan cara memberikan strategi yang berbeda antara laki-laki dan 
perempuan karena laki-laki dan perempuan memiliki potensi yang berbeda. Guru dapat menjadi agen perubahan untuk kesetaraan gender (jenis kelamin) dengan mendukung murid laki-laki maupun perempuan untuk ambil bagian dalam kegiatan tertentu. Guru perlu memberikan mereka tuntunan dan mulai bertindak sebagai panutan (ACDP, 2013: 1).

\section{KESIMPULAN}

Berdasarkan hasil penelitian dapat disimpulkan bahwa kemampuan berpikir kritis dan kemampuanmetakognitif siswa laki-laki dan siswa perempuan pada konsep pencemaran lingkungan tidak menunjukkan adanya perbedaan. Rata-rata kemampuan berpikir kritis siswa laki-laki dan perempuan sebesar 64,2 dan 61,2 termasuk dalam kategori cukup. Kemampuan metakognitif siswa laki-laki dan perempuan memiliki nilai rata-rata sebesar 141 dan 137 sehingga termasuk dalam kategori tinggi. Persentase total kemampuan berpikir kritis semua siswa menggunakan model PBL yang berada pada kategori baik dan sangat baik adalah 51\%, sedangkan persentase kemampuan metakognitif siswa pada kategori tinggi yaitu $91 \%$.

\section{DAFTAR RUJUKAN}

Agustina, L. \& Mulyaratna. 2012. Penerapan strategi belajar metakognitif dalam meningkatkan kualitas belajar siswa pada materi cahaya di kelas VII SMP Negeri 1 Mojokerto. Inovasi pendidikan fisika1 (1): 321-329.

Anita, W. 2015. Pengaruh motivasi belajar ditinjau dari jenis kelamin terhadap kemampuan berpikir kritis matematis mahasiswa. Jurnal Ilmiah UPT STKIP Siliwangi 2(2): 246-251.
Arifin, Z. 2010. Evaluasi pembelajaran. Bandung: Remaja Rosdakarya.

Arikunto. 2009. Dasar-dasar evaluasi pendidikan. Jakarta: Bumi Aksara.

Arikunto. 2012. Dasar-dasar evaluasi pendidikan edisi 2. Jakarta: Bumi Aksara,

Djaali. \& M. Pudji. Pengukuran dalam bidang pendidikan. Jakarta: PT Gramedia.

Hadi, A. 2009. Pengaruh penerapan strategi pembelajaran problem based learning (PBL) terhadap keterampilan metakognitif dan pemahaman konsep siswa kelas $\mathrm{X}$ di SMA Negeri 8 Malang pada kemampuan akademik berbeda.

Jacob, S.M. \&H. K. Sam. 2008. Measuring critical thinking in problem solving through online discussion forums in first year university mathematics. Proceedings of the international multiconference of engineers and computer scientists. Vol I . Hong Kong. 19-21 Maret.

Lambertus. 2009. Pentingnya melatih keterampilan berpikir kritis dalam pembelajaran Matematika di SD. Forum Kependidikan (2). Vol 28. $136-142$

Lidinillah, D. 2007. Pembelajaran berbasis masalah (problem based learning).

Mahanal, S. 2012. Strategi pembelajaran biologi, gender dan pengaruhnya terhadap kemampuan berpikir kritis.

Mamu, H. 2014. Profil keterampilan berpikir kritis dan metakognisi siswa dalam pembelajaran IPA Biologi di SMP. Kreatif 17 (3): 38--48.

Myers, B.E \&J.E. Dyer. 2006. The influence of student learning style on critical thinking skill. In Journal of Agricultural Education. 47 (1): $43-$ 52. 
Nurdin, 2009. Segregasi dalam pengajaran dan penguasaan bahasa. Musawa 1 (1). 63-74.

Nurmaliah, C. 2009. Analisis keterampilan metakognisi siswa SMP Negeri di Kota Malang berdasarkan kemampuan awal, tingkat kelas, dan jenis kelamin. Jurnal Biologi Edukasi. (1): $18-22$.

O’neil, H.F.\&R.S. Brown. 1997. Differential effects of question formats in math assessment on metacognition and affect.

O'neil, H.\& Abedi, J. 1998. Reliability and validity of a state metacognitive inventory potential for alternative assesment. The journal of educational research 89 (4): 234--245.

Purwanto. 2011. Evaluasi hasil belajar. Yogyakarta: Pustaka Pelajar.

Purwanto, N. 2013. Psikologi pendidikan . Bandung: Remaja Rosdakarya.

Riduwan. 2013. Belajar mudah penelitian untuk guru-karyawan dan peneliti pemula. Bandung: Alfabeta.

Romli, M. 2010. Strategi membangun metakognisi siswa SMA dalam pemecahan masalah matematika. Aksioma 1 (2): 1-16.

Rusman, 2012. Model-model Pembelajaran mengembangkan profesionalisme guru. Jakarta:Raja Grafindo Persada.

Sastrawati, E. 2011. Problem-based learning, strategi metakognisi, dan keterampilan berpikir tingkat tinggi siswa. Tekno-Pedagogi1 (2): 1-14.

Sastrawijaya, T. Pencemaran lingkungan. Jakarta: Cipta.

Sudjana, 2008. Penilaian hasil belajar mengajar. Bandung: Remaja Rosdakarya.

Surna, I Nyoman \& Pandeirot. Psikologi pendidikan 1. Jakarta: Erlangga.
Syah, M. 2010. Psikologi pendidikan. Bandung: Remaja Rosdakarya.

Syarifah, H. 2016. Pengaruh strategi pembelajaran reading questioning and answering (RQA) dipadu think pair share (TPS) terhadap keterampilan metakognitif siswa laki-laki dan perempuan SMAN di Kota Malang. Jurnal Pendidikan: Teori, Penelitian, dan Pengembangan 1 (5): 801-805.

Wicaksono, C. 2014. Hubungan keterampilan metakognitif dan berpikir kritis terhadap hasil belajar kognitif siswa sma pada pembelajaran biologi dengan strategi reciprocal teaching. Jurnal pendidikan sains 2(2): 85-59. 